\title{
The Importance of the Study of Bullying in Medical Schools for Training Professional Physicians in Brazil
}

\author{
Lilian Koifman', Sandra de Matos Botelho da Costa ${ }^{2}$ \\ ${ }^{1}$ Department of Health Planning of the Collective Health Institute, Niterói, Brazil \\ ${ }^{2}$ Applied Ethics and Collective Health (PPGBIOS), Niterói, Brazil \\ Email: sandrambotelho@hotmail.com
}

Received 14 February 2016; accepted 3 May 2016; published 6 May 2016

Copyright (C) 2016 by authors and Scientific Research Publishing Inc.

This work is licensed under the Creative Commons Attribution International License (CC BY). http://creativecommons.org/licenses/by/4.0/

(c) (i) Open Access

\begin{abstract}
This research aims to investigate school bullying, specifically in the setting of a Brazilian medical school. It presents part of the results of a doctoral research carried out in the Graduate Program in Bioethics, Applied Ethics and Collective Health (PPGBIOS), in Rio de Janeiro city. We confirm that few studies have investigated this phenomenon in the university, especially using the qualitative research methodology in education and health. It is possible to observe that the phenomenon of school bullying occurs in this setting and that the fieldwork is fundamental to give rise to important reflections on the subject among the students.
\end{abstract}

\section{Keywords}

Bullying, University, Medicine

\section{Introduction}

This research is at the interface between education, bioethics, and collective health. Its object of study is school bullying, especially in the university setting.

The World Health Organization (WHO) defines violence as the use of physical force or power that either results in or has a high likelihood of resulting in injury, death, psychological harm, maldevelopment, or deprivation (WHO, 1996). Bullying is considered as a form of violence to who are added the conceptions of lack of respect for other people, prejudice, and intolerance.

The phenomenon of school bullying - described and recognized globally as a form of violent conduct is manifested among school-age youth and leads to unprecedented harm to health-refers to a type of violent, aggres- 
sive, continuous, and intentional behavior (Olweus, 1993; Smith et al., 2002; Mishna et al., 2006; Swearer et al., 2010; Mitchell \& Borg, 2012; Medeiros, 2012). Its protagonists are mostly school-age youth. Today, bullying can also be observed among university students as a result of a competitive and individualistic culture and also of an extension of adolescence. It makes evident the dynamics of students' interpersonal relationships in the university setting.

As stated by the Brazilian Ministry of Health, adolescents and young adults (from ten to twenty-four years of age) represent $29 \%$ of the world population. Of them, $80 \%$ live in developing countries. In Brazil, adolescents and young adults correspond to $30.33 \%$ of the national population, according to the census carried out in 2010 by the Brazilian Institute of Geography and Statistics (Instituto Brasileiro de Geografia e Estatística-IBGE). A large part of this group enters the university at 17 or 18 years old. The need for knowing and studying school bullying, especially in the university, is then reinforced, since the exposure to bullying may cause problems of different orders for victims, such as stress, lowering or loss of self-esteem, anxiety, depression, low school achievement, and even, in more serious cases, suicide (Boynton-Jarrett et al., 2008).

\section{Literature Review}

Bullying is a theme timidly approached in the university and requires deeper reflections based on the cultural diversity that pervades this setting. It is a form of violence, therefore, its connection to the university setting is based on its harmful effects on students' lives and on their professional training. Much more than compromising the teaching-learning process, its consequences can be seen in everyday life of each student who suffers this harm. Debarbieux (2002) calls attention to the research whose focus is on the psychological issues of the people involved and on their family issues. This author takes into account the social context and the educational policies of elementary schools to deepen his reflections on the phenomenon of bullying.

To face the challenge of understanding this phenomenon more clearly in the university, we make some presumptions: young people grow according to the context of their lives, as well as to the context of their families, and for such they need spaces such as the university, where they can discuss and structure their points of view to grasp more clearly their maturing processes; each young person has his/her own way to deal with the risks to which he/she is usually exposed; everyday life brings into play the most diverse relationships and needs to be thought of carefully to encourage the development of young people's autonomy and self-esteem in the university setting, since, from this point on, they will start their professional lives; cultures and mass media are sources of reference, producing lifestyles and behaviors, and may interfere in the construction of self-image.

According to Sposito (2001), in Brazil, the concern about violence in the school setting began in the 1980s. In the beginning, the studies used to discuss school violence based on the analysis of destruction and damage to school buildings. At the end of the 1990s and beginning of the 2000s, the studies started to address in more detail the issue of aggressive interpersonal relationships involving students, teachers, and other agents of the school community in elementary and secondary schools, without including the university.

Puig (2004), educator and researcher at the University of Barcelona, considers violence in schools as one of the main infirmities of education. For this reason, the reflection on education in a large scenario such as the university is extremely important to understand the interpersonal relationships established there. A better perception of themselves allows students to realize how they can be affected by their experience with the other. Individualistic, competitive, and even aggressive actions, very common in contemporary social coexistence, are usually reproduced in the school setting and may express discrimination, intolerance, and lack of respect to others. Silva (2010) indicates fear as a persistent factor that might torment students and, subsequently, destroy all their potential in class, which may lead to consequences in the shaping of future physicians for professional practice.

In general, violence in the university setting happens when there is no room for listening or talking. Lopes Neto (2005) stresses that, when there are no means to channel aggression, the result shows as poorly managed conflict. In contemporary society, as violence is seen as something banal, the importance of listening and talking to the students is overlooked. We must also mention here the cultural diversity that pervades the Brazilian university setting, so that we can comprehend more fully the phenomenon of bullying there. The Brazilian National Curriculum Parameters (Parâmetros Curriculares Nacionais-PCNs) emphasize that the greatest challenge for schools is to recognize diversity as an inseparable part of national identity and to make known the richness represented by ethnic and cultural diversity in the composition of the Brazilian sociocultural heritage, aiming to overcome any form of discrimination (Brasil, 1998).

Conflict is part of human development, and the university, setting of many conflict situations, is a suitable 
place for the sectors of education and health to develop joint actions to understand it better. In this sense, we observed that it is extremely important that professors take part in a continuing and open dialogue with students, a dialogue that, as a human phenomenon, will reveal words, suggesting action and reflection. The professors' attentive listening and look will contribute to identify the role of each individual or group to understand students' different behaviors. Freire (2011) discusses the importance of knowing how to listen, since it is by listening to the youth that we learn how to communicate with them. A democratic motivation for listening and looking attentively to the students might change the educators' discourse towards the construction of freedom and creativity.

We can list some documents of the Brazilian law referring to the issue of students' rights to respect and dignity. The Constitution of the Federative Republic of Brazil, promulgated in 1988, underlines the importance of a fraternal society anchored in values as justice, freedom, equality, and the welfare of citizens. It is also important to highlight the Act n. 9.394 of 20 December 1996, which provides the tenets and guidelines of national education (Brasil, 1996), the PCNs (Brasil, 1998), and the Act n. 8.069 of 13 July 1990, known as the Child and Adolescent Act (Estatuto da Criança e do Adolescente-ECA; Brasil, 1990).

Cortella and La Taille (2009) state the importance of knowing an individual's ethical perspective to perceive clearly the process that makes this individual respect certain moral principles or rules. Conflicts and their connection to fast-paced social changes indicate the need for looking to the youth as a whole, with the intention of not only acquiring knowledge, but also thinking about their relational and affective experiences with peers. This will be fundamental to build a solid foundation to support the professional life the medical student will have to lead.

According to La Taille (2006), a better understanding of human behavior should be based on the ethical perspective that drives individuals in different conflict situations throughout their lives. Along this line of thought, it becomes essential to shed light on cases of bullying in the university, a setting of social-moral actions that must be considered not only from the students' perspective, but also from that of the professors who face the phenomenon.

The reproduction of this behavior may occur in the university with detriment to the encouragement of dialogue and listening as mechanisms of negotiation. When the behavior persists, it often leads to negative consequences for the victims from the emotional, intellectual, and social point of view. As an example, one can observe lowering self-esteem, increasing levels of anxiety, and even episodes of depression that make difficult to integrate young people into the university setting. Consequently, the acquisition of new learning is limited and students suffer an emotional damage that may last until adult life, putting their professional training at risk.

It is necessary that continual efforts be made on the part of all those involved in the education process to understand and minimize this phenomenon. Attention should turn not only to developing students' cognitive abilities, but also to developing moral values to strengthen their sense of autonomy and citizenship in the university. Concurrently with scientific learning and technical training, the aspects related to feelings and emotions should be considered. Humiliation, aggression, and violence should be seriously inhibited in a setting where what is expected is the development of education in its broader sense, which will culminate in professional training.

When students enter the university, they encounter the culture of "university hazing", traditional in many societies. It means that activities to welcome freshmen ("calouros", as they are called in Brazilian universities) joyfully and festively, many times end up being a real torment. In many Brazilian educational institutions, hazing is a practice that causes serious embarrassment, in addition to the violence often present in the actions of the students who were supposed to welcome freshmen. Calhau (2010) mentions that older students are replaced by newer students in the practice of hazing, but advises that violent hazing persists, and many times ends up as extreme cases of physical abuse, heavy drinking, sexual harassment, or dives in manure or mud puddles.

Villaça and Palácios (2010) warn against the psychological and physical repercussions of violent hazing, which may often have serious consequences for students, including death. These authors stress another important aspect to be observed: students do not denounce violent acts for fear of peer retaliation.

Palácios and Rego (2006) highlight the importance of virtual communities for measuring bullying. Virtual spaces may encourage the establishment of protection and support networks, but, on the other hand, we have to consider the weight of virtual communities that incite to violence, either as hazing proper or as bullying.

\section{Method}

This article shows the first results of a doctoral research in the Graduate Program in Bioethics, Applied Ethics and Collective Health (Programa de Pós-Graduaçãoem Bioética, Ética Aplicada e Saúde Coletiva-PPGBIOS), 
an association of the following Brazilian universities: Federal University of Rio de Janeiro (Universidade Federal do Rio de Janeiro-UFRJ); Fluminense Federal University (Universidade Federal Fluminense-UFF); State University of Rio de Janeiro (Universidade Estadual do Rio de Janeiro-UERJ); e Oswaldo Cruz Foundation (Fundação Oswaldo Cruz-Fiocruz). The doctoral research was approved by the Committee of Ethics in Research of the Medical School of the Fluminense Federal University/Antônio Pedro University Hospital, linked to the Brazil Platform—Brazilian Ministry of Health (PlataformaBrasil—Ministério da Saúde do Brasil).

This is a qualitative research carried out at a public medical school in Brazil to check the occurrence of school bullying among medical students. Its sample was made up of 20 medical students, five from each term of medical school up to the fourth term, which corresponds to approximately five per cent of each class of 90 students.

Few bullying experiences have been investigated within the university setting, especially using qualitative health research. According to Minayo (2004), qualitative research specifies how important it is to reduce the number of participants when forming groups, so that participants have more freedom to express their ideas. In this author's own words: “[...] together with life history, open or semi-structured interviews, and participant observation, the researcher builds a series of possibilities for information (Minayo, 2004).

After introducing the research to the students, we chose from each term the first five students willing to take part in the study until there was a total of 20 students, who were then divided in four groups of five, each group corresponding to one term. Next, the students were invited to sign a TCLE. Consistent with the steps of qualitative research methodology, the students who did not want or who could not take part in the research were excluded.

Our first results were obtained from five medical students who were enrolled in the second term when we collected the first data for the research, in October 2015. They were between 20 and 26 years old and belonged to different social classes, since the university is a tuition-free public institution that admits students regardless of their families' economic situation. In fact, the students were mostly from the middle or high social classes. Students from low-income families seldom enter medical schools. A gender predominated in the group, but we decided not to declare it to protect students from being identified.

Following the recommendations provided in the Resolution 466/2012 of the Brazilian National Health Council, the participant students signed an informed consent (Termo de Consentimento Livre e Esclarecido-TCLE). The results of the other 15 students are still being evaluated according to other variables. In the next phases of the study, we will relate these findings to questions about students' body image and moral values.We opted for the participation of students from the first four terms of medical school, because they were younger and, probably, more vulnerable to bullying.

The following methodological procedures were used: 1) application of a questionnaire, totaling 23 questions, of which ten were semi-structured and thirteen were structured; 2) participant observation, with the production of a field $\log$ by the researcher. We first analyzed each individual participant's responses, then combined these to look at a comprehensive overview of all responses.

According to Tavares and Campana (2009), the qualitative approach allows to see the problem and its surroundings from a broader perspective, giving emphasis to data collection strategies such as field observations and questionnaire application, with open or semi-structured questions.

\section{Results}

Although in the setting under study age varies considerably among students enrolled in the same term, the analysis of research data has not shown that this variation was significant for the discussion about bullying.

Only one student's family lives in the same city where the research was conducted. The families of three of the participating students live in different towns in another Brazilian state, and one student's family lives in the capital city of another Brazilian state. All have different education backgrounds, because of Brazil's huge cultural diversity, considering its size and the different colonization histories of its many regions.

Although in the random sample of five students of the second term a gender has prevailed (feminine or masculine), we decided not to declare it here to protect participants from being identified.

Of the five participant students, two reported having been bullied in the university. The first student reported bullying experiences in two different moments: 1) cyberbullying in a WhatsApp group with classmates, when a comment this student made was posted in another WhatsApp group with students of a different class, characterizing a form of psychological abuse, since this student did not want the comment to be shared with other groups; 
2) bullying during hazing, when this student entered the university and was forced to sing racist, sexist, and defamatory songs. Although no type of violence has been reported, this student did not feel comfortable with that kind of joke and took part in it just to not be discriminated against. The second student reported having suffered verbal abuse because of a physical trait. Reporting humiliation and indignation in that situation, the student said: "I felt sad, embarrassed".

With regard to witnessing bullying in the university, all five students reported having seen some incidents, but only two reported having interfered and adopted an attitude. The others have not felt comfortable to help, either for fear or for not knowing what to do in that situation. According to one of the students: "Some laugh, others do not like it, most pretend it is a joke", all think that bullies are always in groups and, for that reason, they feel powerful. The participant students reported that bullying occurs in all places in the university, from classrooms to parties, during breaks between classes, and virtually, too, in Facebook and other internet groups, such as WhatsApp.

As to practicing bullying, none of the students reported taking part in it. However, one of them asked the researcher whether a joke related to a classmate's physical trait could be considered bullying, and reflected about this question during the research beside that same classmate.

All students had questions about whether the individual who practices this form of violence knows exactly the harm it causes to victims. One of the participant students said: "I perceive that the bullies in my class do not seem to think about what their action might cause". At that moment in the conversation, we realized how reflecting on the subject, an opportunity provided by the research, was important to encourage questions and thoughts from students.

Emotions played a significant role in how victims, bullies or bystanders perceived themselves regarding the bullying incidents. While victims felt embarrassed, helpless, scared and rejected, bullies felt powerful, significant, and superior to others.

Bullying can have negative lifelong consequences for both the students who bully and for their victims.

In our research, the qualitative approach gave room for some students' important comments on the subject while they were answering the questionnaire. We believe that it is extremely relevant to promote the dialogue on bullying in the university to inhibit this type of behavior among Brazilian higher-education students.

\section{Discussion and Conclusion}

The study of bullying has been conducted all over the world. However, few of these studies have investigated the phenomenon in the university, especially using qualitative research in education and health.

In Brazil, medical schools have the most competitive entrance examinations. This makes difficult for young people to be admitted at their first attempt, since very high scores are needed to be admitted. The immediate consequence is that most students have to take the examination more than once. Therefore, in general, these students start at the university a little older than they were when taking the first examination. The second-term students who took part in this research were between 20 and 26 years old, for instance.

Many students start their studies in private medical schools, but keep trying a place in public institutions. The cost of attending a private university, paid with students' and their families' own resources, is very high in Brazil, which is also a factor for narrowing the entrance to public institutions.

Brazilian society influences the establishment of ideal beauty patterns. It is known that body changes in the adolescence bring about self-image problems for the youth and that each age has its own beauty references. In general, when answering the research questions, the youth demonstrated some concern with their appearance. This research made them reflect whether insulting classmates for their appearance, even non-aggressively, just as a joke, can be considered as a form of bullying. They reflected about this issue in a kind way beside the classmate whose appearance they used to ridicule, but thinking about their attitude toward him.

After answering the questionnaire, the participant students commented on the moment they entered the university. Of the five students, four come from a Brazilian state other than the one where the research was conducted, and, of these four, two started their studies in a university in their state of origin. These two students reported that hazing had been very violent there. They found it difficult to talk about the subject and provided no details. They pointed out many differences in relation to the hazing practiced in the university where this research was carried out, considering it as a joke when compared to the hazing they had previously witnessed. In the university community under study, it became clear that sociocultural patterns from family, school and the 
media might influence the understanding of the dynamics of bullying among medical students.

Concerning the family, the changes we observe today in its structure show different forms of organization, according to the lifestyle and the needs of each specific group. With regard to school, we perceive that, over time, this institution's social function, mission, and organization have taken on different meanings. Today, it is seen as a social space that develops teaching and learning processes that include actions in its own territory and in its surroundings.

In this direction, understanding existing differences and establishing a favorable environment for coexistence, where conflicts can be managed, require we know the reality and everyday life of students, professors, educational institutions, and communities. The function of the university as an adequate setting to deal mainly students' issues is unquestionable.

This is the place to acknowledge the students' commitment to this study, giving part of their time for the activities proposed. With this attitude, they have created an important opportunity for reflecting beyond the curriculum information received in the classroom.

The development of a program of attention to the health and education of young university students requires the connection of individual needs to collective needs to overcome a vision focused on more specific pedagogical issues. A comprehensive orientation, including social and cultural dimensions, arises as a challenge to be faced.

This study highlights the importance of qualitative research in health and education for studying the phenomenon of bullying. We emphasize that it is crucial for different social segments to discuss thoroughly a phenomenon that causes so much harm in the life of youth all over the world.

Concerning our fieldwork, the great challenge was to give students the opportunity to express freely in their answers to the questionnaires, holding a dialogue with them to explain and comment on the theme without losing the focus on research objectives. We realized that the most important was to be willing and open to listen to and understand the ideas shared among the students and their experiences, and opening space for reflection on the daily relationships among them and the university.

The role of teachers and professors is extremely important, especially to establish in the classroom attitudes of mutual respect among students, even among university students. Some students pointed out the moment of presenting papers in the classroom as a driving force for bullying students with lower verbal ability. Fostering dialogue is fundamental to promote good relationships among students, therefore, professors can play a major role to exclude the phenomenon of bullying from university life.

Koifman and Saippa-Oliveira (2006) stress the relevance of explaining the pedagogical praxis and the knowledge behind it to students as a path to a historical construction of citizenship. Thus, in the mechanisms of legitimation and conflict, it would be possible to find how to connect, interchange, and show solidarity as a response to diversity.

In this research, we conclude that the phenomenon of bullying is closely related to socially established stereotypes and prejudice. Accepting the differences between human beings-differences that we come across in each moment of our lives, and not only at school—is an ideal way to confront bullying. It becomes essential to rethink the fundamental role of the university in dealing with bullying to build a democratic society.

In our research hypotheses, we consider that there are cases of bullying among university students. In this first contact with the five participant students from the second term of medical school, we observe that this phenomenon exists and that fieldwork is essential to give students the opportunity to talk about the subject, as well as to provoke important reflections among them.

In the next phases of the study, we will relate these findings to questions about students' body image and moral values.

\section{References}

Boynton-Jarrett, R., Ryan, L. M., Berkman, L. F., \& Wright, R. J. (2008). Cumulative Violence Exposure and Self-Rated Health: Longitudinal Study of Adolescents in the United States. Pediatrics, 122, 961-970. http://dx.doi.org/10.1542/peds.2007-3063

Brasil (1996). Lei $n^{\circ}$ 9.394, 20 de dezembro de 1996 [Act n. 9.394 of 20 December 1996]. Estabelece as diretrizes e bases da educação nacional [Provides the Tenets and Bases of National Education]. Diário Oficial da União [Federal Official Gazette].

Brasil. Secretaria de Educação Fundamental [Elementary Education Department]. (1998). Parâmetros curriculares nacionais: 
Terceiro e quarto ciclos do ensino fundamental: Introdução aos parâmetros curriculares nacionais [National curriculum parameters]. Brasília: MEC/SEF, 174 p. 1. Parâmetros curriculares nacionais [National curriculum parameters]. 2. Ensino de quintaaoitavaséries [Education from the Fifth to the Eighth Grade]. I. Title. CDU: 371.214.

Brasil (1990). Lei No 8069/90 [Act N. 8069/90]. Estatuto da Criança e do Adolescente [Child and Adolescent Act].

Calhau, L. B. (2010). Bullying, o que você precisa saber: identificação, prevenção e repressão [Bullying, What You Need to Know: Identification, Prevention, And Repression] (2nd ed.).Niterói, RJ: Impetus.

Cortella, M., \& La Taille, Y. (2009). Nos Labirintos da Moral [In the mazes of moral] (6th ed.). Campinas, SP: Papirus.

Debarbieux, E. (2002).Violências nas escolas: Divergências sobre palavras e um desafio político. In E. Debarbieux, \& C. Blaya (eds.), Violências nas escolas e políticas públicas. Translated into Portuguese by Patrícia Zimbres. Brasília: Unesco. Original Title: Violence in School and Public Policies. Paris: Elsevier. http://unesdoc.unesco.org/images/0012/001287/128720por.pdf

Freire, P. (2011). Pedagogia da Autonomia: Saberes necessários à prática educativa [Pedagogy of Autonomy: Knowledge Necessary for Educational Practice]. São Paulo: Paz e Terra.

Koifman, L., \& Saippa-Oliveira, G. (2006). Produção de conhecimento em saúde [Knowledge Production in Health]. In: Ensinar saúde: A integralidade e o SUS nos cursos de graduação na área da saúde [Teaching Health: Integrality and the Unified Health System in Health Undergraduate Programs] (2nd ed.). Rio de Janeiro: IMS/UERJ-Cepesc-Abrasco.

Lopes, N. A. (2005). Bullying: Comportamentoagressivo entre estudantes [Bullying: Aggressive Behavior Among Students]. Jornal de Pediatria [Journal of Pediatrics], Rio de Janeiro, 81, 164-172.

La Taille, Y. (2006). Moral e ética: Dimensões intelectuais e afetivas [Moral and Ethics: Intellectual and Affective Dimensions]. Porto Alegre: Artmed.

Mishna, F., Pepler, D., \& Wiener, J. (2006). Factors Associated with Perceptions and Responses to Bullying Situations by Children, Parents, Teachers and Principals. Victims and Offenders, 1, 255-288. http://dx.doi.org/10.1080/15564880600626163

Medeiros, A. V. M. (2012). O fenômeno bullying: (In)definições do termo e suaspossibilidades [The Bullying Phenomenon: Term (In)definition and Its Possibilities]. Master's Thesis in Sociology, Goiânia: Federal University of Goiás.

Mitchell, D. M., \& Borg, T. (2012). Examining the Living Experience of Bullying: A Review of the Literature from an Australian Perspective. Pastoral Care in Education, 31, 142-155. http://dx.doi.org/10.1080/02643944.2012.747554

Olweus, D. (1993). Bullying in School: What We Know and What We Can Do. Oxford: Blackwell.

Palácios, M., \& Rego, S. (2006). Bullying: Mais uma epidemia invisível [Bullying: One More Invisible Epidemics]? Revista Brasileira de Educação Médica [Brazilian Journal of Medical Education], 30, 3-5.

Puig, J. M. (2004). Práticas Morais: Uma abordagem sociocultural da educação moral [Moral Practices: A Sociocultural Approach of Moral Education]. São Paulo: Moderna.

Silva, A. B. B. (2010). Bullying: Mentes perigosas nas escolas [Bullying: Dangerous Minds in the School]. Rio de Janeiro: Objetiva.

Smith, P., Cowie, H., Olafsson, R. F., \& Liefoogh, P. D. (2002). Definitions of Bullying: A Comparison of Terms Used, and Age and Gender Differences, in a Fourteen-Country International Comparison. Child Development, 73, 1119-1133. http://dx.doi.org/10.1111/1467-8624.00461

Minayo, M. C. S. O. (2004). Desafio do conhecimento: Pesquisa qualitativa em saúde [The Challenge of Knowledge: Qualitative Research in Health] (3rd ed.). São Paulo: Hucitec.

Swearer, S., Espelage, D. L., Vaillancourt, T., \& Hymmel, S. (2010). What Can Be Done About School Bullying? Linking Research to Educational Practice. Educational Researcher, 39, 38-47. http://dx.doi.org/10.3102/0013189X09357622

Sposito, M. P. (2001). Um breve balanço da pesquisa sobre violência escolar no Brasil [A Brief Stock of Research on School Violence in Brazil]. Educação e Pesquisa [Education and Research], 27, 87-103.

Tavares, M. C. G. C. F., \& Campana, A. N. N. B. (2009). Avaliação da imagem corporal: Instrumentos e diretrizes para pesquisa [Body Image Assessment: Instruments and Guidelines for Research]. São Paulo: Ed. Phorte.

Villaça, F. M., \& Palácios, M. (2010). Concepções sobre assédio moral: Bullying e trote em uma escola médica [Concepts about Moral Harassment: Bullying and Hazing in a Medical School]. Revista Brasileira de Educação Médica [Brazilian Journal of Medical Education], 34, 506-514.

WHO, World Health Organization. Global Consultation on Violence and Health (1996). Violence: A Public Health Priority. Geneva: WHO. 


\section{Appendix}

\section{Questionnaire}

Dear student: please, answer the questions individually. Your answers are confidential. Thank you for taking part in this research.

Name:

Age: $\quad$ Sex: ( ) $\quad$ Female ( ) Male ()

\section{List of Questions about Bullying}

1) Do you have a good relationship with your classmates?

( ) Yes ( ) No Please, justify your answer:

2) Where in the university do teasing and jokes among students occur?

3) Have you ever been intimidated by other university student?

( ) Yes ( ) No

If yes:

( ) By a classmate ( ) By a student from another class ( ) By an older student State the type of aggression you have suffered:

( ) Physical: kicking, beating, pinching

( ) Verbal: swearing, mocking, nicknaming

( ) Psychological: threatening, persecuting, intimidating

( ) Virtual: emailing, cell phoning

Please, report what happened:

4) Have you ever witnessed a student being intimidated by other in the university?

( ) Yes ( ) No

If yes, give the details:

( ) Physical: kicking, beating, pinching

( ) Verbal: swearing, mocking, nicknaming

( ) Psychological: threatening, persecuting, intimidating

( ) Virtual: emailing, cell phoning

Please, report what happened:

5) Have you done anything to help the victim or prevent the act?

$$
\text { ( ) Yes ( ) No }
$$

If yes, why?

6) You observed that students who intimidate others:

( ) Belong to a group or ( ) Are always on their own

7) Is any student intimidating you now?

\section{( ) Yes ( ) No}

If yes, how do you react to provocations? What does the other student do?

8) Have you ever performed, suffered or witnessed bullying in the university?

( ) Yes ( ) No

What were your feelings:

-when you performed bullying?

-when you suffered bullying?

-when you witnessed bullying?

9) Do you perceive other students' feelings towards bullying:

-when they perform the actions?

-when they suffer the actions?

-when they witness the actions?

10)When you started university, have you experienced hazing?

( ) Yes ( ) No

If yes, please, detail how it happened:

If no, please, explain why you did not take part in it: 
2. List of Questions about Body/Body Image

1) Do you worry about your physical appearance?
( ) Yes
( ) No
( ) Sometimes

2) Do you feel comfortable with your body?
( ) Yes
( ) No
( ) Sometimes

3) Do you worry more about your physical appearance when you are with other people?

( ) Yes ( ) No ( ) Sometimes

4) Do you think people's success depends on how they dress?
( ) Yes
( ) No
( ) Sometimes

3. List of Questions about Sociocultural Attitudes Related to Body/Body Image and the Media

1) Have you ever felt encouraged to work out by TV or other media?
( ) Yes
( ) No
( ) Sometimes

2) Have you ever felt encouraged to change your appearance by TV or other media?
( ) Yes
( ) No
( ) Sometimes

\section{List of Questions about the Media}

1) Which media do you use?

( ) Television ( ) Magazines ( ) Radio ( ) Newspapers ( ) Internet ( ) Cell phone

2) Do you feel you are part of a group? Is there any behavior, taste, or dress codes among your friends?
( ) Yes
( ) No
( ) Sometimes

\section{List of Questions about Family}

1) Does your father/the person you live with comment on your physical appearance?
( ) Yes
( ) No
( ) Sometimes

2) Does your mother/the person you live with comments on your physical appearance?

( ) Yes ( ) No ( ) Sometimes

3) Do you talk with your siblings about physical appearance?
( ) Yes
( ) No
( ) Sometimes

\section{List of Questions about Your Observation and Your University Mates' Observation Concerning} the Body/Body Image

1) Do you notice your university friends and mates' physical appearance (shape, weight, clothes)?
( ) Yes
) No
( ) Sometimes

2) Do your university friends and mates comment on your physical appearance (shape, weight, clothes)?
( ) Yes
( ) No
( ) Sometimes 